\title{
Estimation of the Experimental Drying Performance Parameters Using Polynomial SVM and ANN Models
}

\author{
Kamil Neyfel Çerçi (1), Doğan Burak Saydam* (i), Ertaç Hürdoğan \\ Osmaniye Korkut Ata University, Faculty of Engineering, Department of Energy Systems Engineering, 80000, Osmaniye, Turkey
}

\begin{abstract}
The utilization of solar energy in Turkey is very popular because of yearly high solar radiation compared to other countries. One of the common usage area of solar energy is food drying processes. Foods are generally dried under direct sunlight. However, the quality of the dried product exposed to solar radiation reduces. Additionally, the food product dried in outdoors is also exposed to the negative effects of the external environment and thus adversely affects the product quality. In order to overcome these problems, many studies are carried out on solar assisted drying systems. It is very important to calculate or modeling the drying parameters for the design of solar assisted drying systems. In recent years, interest on calculative intelligence methods increases due to the fact that it has high predictive power in modeling of systems. In this study, performance parameters such as solar collector efficiency $\left(\eta_{c}\right)$, drying rate (DR) and convective heat transfer coefficient $\left(h_{c}\right)$ obtained from a solar energy assisted dryer for different products were estimated by Support Vector Machine (SVM) and Artificial Neural Network (ANN) models. Apple, red pepper and green pepper were chosen as the product to be dried. The accuracy criteria of the predicted results for each model were determined and compared. It was shown from the results that the best converging models of DR and $\eta_{c}$ parameters were ANN and SVM ${ }_{c}$, respectively. However, it was observed that $S V M_{L}$ was the best convergent model for $h_{c}$ values obtained from apple product, and ANN model was the best convergent model for $h_{c}$ values obtained from other products.
\end{abstract}

Keywords: Drying, Solar Energy, Performance parameter, SVM, ANN.

\section{INTRODUCTION}

The drying, which is one of the oldest techniques used for food or agricultural products storage, is the basic process to reduce moisture from product [1]. Food drying is a complicated process where simultaneous heat and mass transfer take place. Removing the moisture from the product is the main principle of drying process [2]. The drying process begins with the solution of the bond forces between water and the product to be dried. This process requires a certain amount of energy. This energy (heat energy) should be given to the material without interruption during the drying period [3]. Solar energy is a clean energy source that is very popular especially in drying applications [4]. Turkey's average annual total sunshine duration is $2640 \mathrm{~h}$ (daily total is $7.2 \mathrm{~h}$ ), and average total irradiation is $1311 \mathrm{kWh} / \mathrm{m}^{2}$-year (daily total is $3.6 \mathrm{kWh} / \mathrm{m}^{2}$ ). Turkey located between $36^{\circ} \mathrm{N}$ and $42^{\circ} \mathrm{N}$ latitude have an advantageous geographical location for solar energy [5]. Open sun drying is the most common method used to preserve agricultural products in most countries. However, this technique is affected from weather conditions and has the problems of contamination with dust, soil, sand particles, insects, the length of drying time, loss of time and product loss [6]. Solar energy assisted dryers are designed to eliminate these effects and reduce drying time [7].

There are many studies in the literature about solar energy assisted drying systems [8-17]. Çerçi and Akpınar [9] have developed a greenhouse type dryer. Drying process was performed in open sun drying and greenhouse type drying. Drying processes were carried out in the greenhouse dryer using natural and forced convection mode. They found that convective heat transfer coefficient values were $2.863 \mathrm{~W} /$ $\mathrm{m}^{2} \mathrm{~K}$ for under open sun drying, $2.065 \mathrm{~W} / \mathrm{m}^{2} \mathrm{~K}$ for greenhouse drying with natural convection mode and $2.724 \mathrm{~W} /$ $\mathrm{m}^{2} \mathrm{~K}$ for greenhouse drying with forced convection model. Sagia and Fragkou [16] made mathematical modelling with thin layer drying models by using experimental data obtained from various studies on drying behavior of fungi. They found that mathematical models are useful for modelling and analysis of heat and mass transfer during drying processes.

In recent years, many researchers have realized studies with 
different machine learning approaches [18-23]. In this study, drying performance parameters such as solar collector efficiency $\left(\eta_{c}\right)$, drying rate (DR) and convective heat transfer coefficient $\left(h_{c}\right)$ for different food products were estimated using polynomial Support Vector Machine models (SVM) and Artificial Neural Network model (ANN). The aim of this study is to determine the most appropriate computational intelligence method that can be used to determine different drying performance parameters and to present a sample study to the literature with these models. Parameters considered for the estimation were obtained from a study presented by the authors in the literature [24]. In the study, apple, red pepper and green pepper slices were dried using a solar energy assisted dryer while the system and experimental procedure was described in more detail elsewhere [24]. Matlab software was used for analysis and modelling.

\section{MATERIAL METHOD}

Figure 1 shows the schematic view of the solar assisted drying system used in the study $[2,3,7,24]$. As can be seen from the figure, system consists of two main sections: a solar air collector and a drying chamber. The ambient air entering the solar air collector (state 1) is heated in the collector and sends to the drying cabinet (state 2 ) via a blower. Drying air takes the moisture from the food product and leaves from the system (state 3 ). In the system, the case of the air solar collector with a size of $195 \times 95 \times 12 \mathrm{~cm}\left(1.70 \mathrm{~m}^{2}\right)$ was made of plexiglass and its lower and side surfaces were covered with glass wool insulation material to reduce heat losses. For the circulation of air, a speed controlled radial blower with 70W power and $650 \mathrm{~m}^{3} / \mathrm{h}$ of flow rate (max.) was used. In order to prevent air leaks, all the connection points and spots, where air passes, are closed using silicon. Possible heat losses were prevented by covering the drying chamber with aluminum coated glass wool mattress with $5 \mathrm{~cm}$ thick. The drying chamber in which the products are placed was made of wood. The crops to be dried were placed inside the drying chamber with the help of a tray. The chamber also contains a sight glass made of transparent plastic material for the monitoring of the products. A tray of approximately $0.5 \mathrm{~m}^{2}$, on which the products are dried inside the dryer, was manufactured from aluminum perforated wire to allow the air passage. The products with a thickness of $4 \mathrm{~mm}$ were placed homogeneously on the tray. After the products were placed in the drying chamber by means of the tray through the product inlet, the tray was connected to the electronic precision scale with the hanger system inside the chamber.

Measurements were made at different points on the system to determine the performance of the system and the drying characteristics of the products to be dried (Figure 1). A computer aided data acquisition system was used to measure different parameters (temperature, moisture, air velocity, weight and radiation) and to record the data at 15 min intervals. In addition to the temperature measurements carried out in the collector, blower and at the entrance and exit of

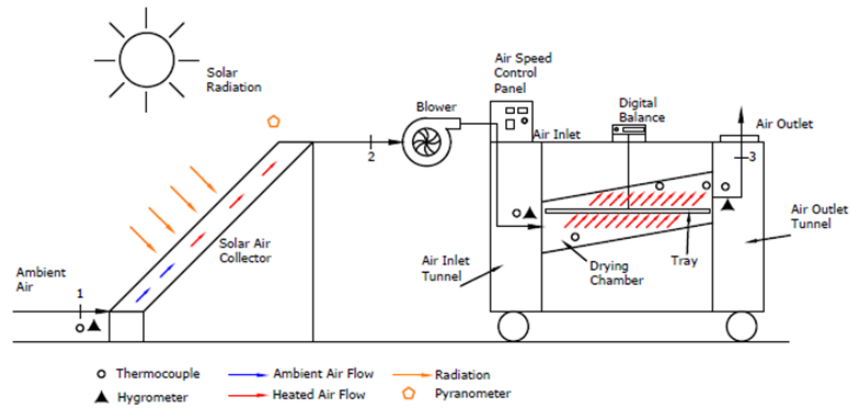

Figure 1. Schematic views of air collector drying system $[2,3,7,24]$

the drying chamber, relative humidity was also measured at the collector inlet (ambient air) and at the entrance and exit of the drying chamber. The solar radiation was measured with an irradiation sensor placed in such a way that it has the same slope as that of the collector. In order to determine the air flow rate circulating in the system, the air velocity was measured using an anemometer in the air tunnel located at the outlet of the drying chamber [24]. Error analysis was performed using the method proposed by Holman [25]. Table 1 contains information about the devices used to make measurements in the system and about the error analysis.

Table 1. Devices used in measurements and the uncertainty of the calculated parameters.

\begin{tabular}{|c|c|c|}
\hline Measurement & Device & Accuracy \\
\hline Temperature & COLE PARMER K type thermocouple & $0.1^{\circ} \mathrm{C}$ \\
\hline Relative humidity & EPLUSE humidity transmitter & $2-3 \%$ \\
\hline Weight & DiKOMSAN electronic balance & $0.1 \mathrm{~g}$ \\
\hline Air velocity & TESTO 435 with air speed probe & $0.1 \mathrm{~m} / \mathrm{s}$ \\
\hline Solar Radiation & TRITEC Irradiation sensor & $\pm 5 \%$ \\
\hline Data recording & IOTECH PD3001data logger & 16 bit \\
\hline & & \\
\hline $\begin{array}{c}\text { Calculated Para- } \\
\text { meter }\end{array}$ & & Uncertainty \\
\hline$h_{c}$ & & 3.88 \\
\hline DR & & 2.70 \\
\hline$\eta_{c}$ & & 2.88 \\
\hline
\end{tabular}

\section{CALCULATIONS}

In the study, $\eta_{\mathrm{c}}$ is calculated by using Equation $1[24,26]$. The DR is calculated by using Equation 2 [24, 27]. The $h_{c}$ value is calculated using expression of Nusselt number $(\mathrm{Nu})$ by Equation (3) and Equation (4) $[18,24,28]$. The utilized heat rate for evaporating moisture is calculated by using Equation (5) $[18,24,28]$. Table 2 gives the equations used for calculations.

Where, , is moisture evaporated $(\mathrm{g}), \mathrm{A}_{\mathrm{c}}$ is collector are $\left(\mathrm{m}^{2}\right)$, I is solar radiation $\left(\mathrm{W} / \mathrm{m}^{2}\right), \mathrm{C}_{\mathrm{p}}$ is specific heat of air $(\mathrm{J} / \mathrm{kg}$ $\left.{ }^{\circ} \mathrm{C}\right)$, is mass flow $(\mathrm{kg} / \mathrm{sec}), \mathrm{T}_{\mathrm{e}}$ is outlet temperature $\left({ }^{\circ} \mathrm{C}\right), \mathrm{T}_{\mathrm{i}}$ is inlet temperature $\left({ }^{\circ} \mathrm{C}\right), \mathrm{K}_{\mathrm{v}}$ is thermal conductivity of humid air $\left(\mathrm{W} / \mathrm{m}^{\circ} \mathrm{C}\right), \mathrm{X}$ is characteristic dimension $(\mathrm{m}), \mathrm{C}$ and $\mathrm{n}$ are constants, Re is Reynolds number, Pr is Prandtl number, is evaporating moisture, $\mathrm{T}_{\mathrm{p}}$ is product temperature $\left({ }^{\circ} \mathrm{C}\right), \mathrm{T}_{\mathrm{c}}$ is chamber temperature $\left({ }^{\circ} \mathrm{C}\right), \mathrm{A}_{\mathrm{t}}$ is tray area $\left(\mathrm{m}^{2}\right)$, $\mathrm{t}$ is time (second), $\lambda$ is latent heat of vaporization, $\rho_{\mathrm{v}}$ is density of humid 
air $\left(\mathrm{kg} / \mathrm{m}^{3}\right), \mu_{\mathrm{v}}$ is viscosity $(\mathrm{kg} / \mathrm{ms})$.

Table 2. The equations used for calculations

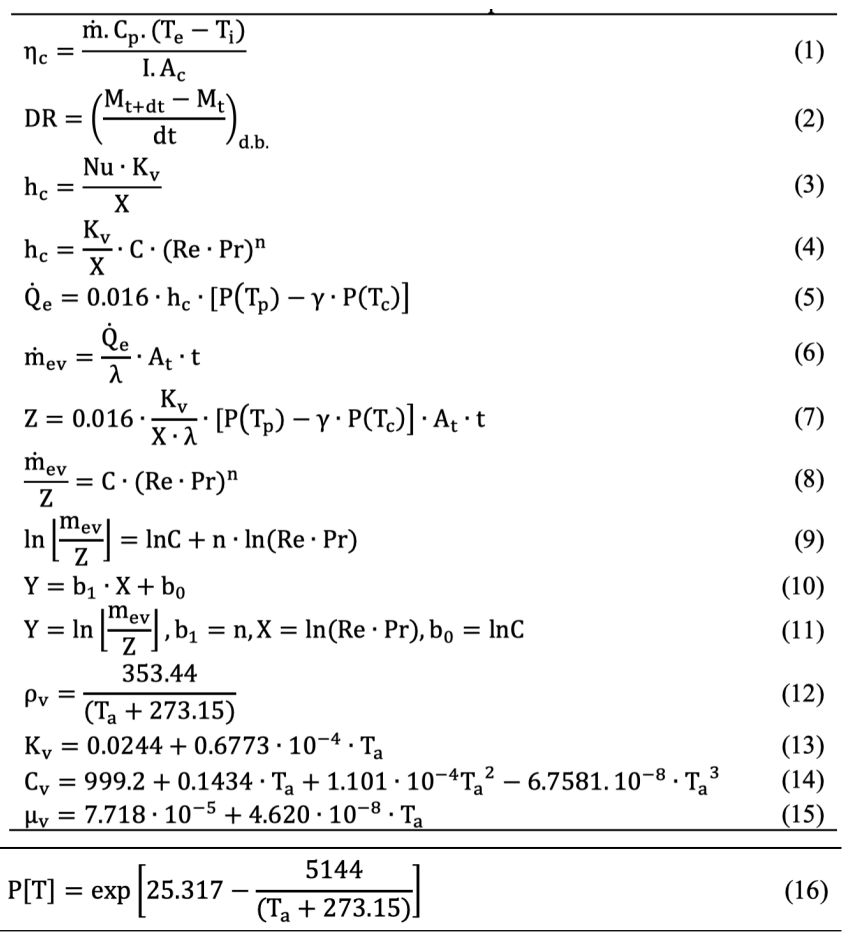

\subsection{Support Vector Machine (SVM)}

It is stated that the SVM method, which is one of the important types of machine learning, provides successful results for many different fields in the recent years [29-33]. Support vector machines are learning systems using the hypothesis field of linear functions in a multi-dimensional feature area and this learning strategy was first developed by Vapnik [34]. In addition to the classification of SVM with linear separator hyper plane, there may also be situations where linear separation cannot be made in the original input field. In these cases, functions called kernel are used. The kernel converts the linear problem to non-linear problems by mapping to property fields. Radial-based, polynomial and two-layer sigma neural networks are some of these core functions [35]. In this study, the polynomial kernel function was used to estimate the performance parameters of the solar-assisted drying system for the drying of different food products. Three different polynomial kernels used in this study are linear-degree $1\left(\mathrm{SVM}_{\mathrm{L}}\right)$, quadratic-degree $2\left(\mathrm{SVM}_{\mathrm{Q}}\right)$ and cubic-degree $3\left(\mathrm{SVM}_{\mathrm{C}}\right)$. The basic kernel functions and parameters used in support vector machines is given Equation $17[34,36]$.

$$
K(x, y)=((x \cdot y)+1)^{d}
$$

\section{3.2. ARTIFICIAL NEURAL NETWORK (ANN)}

An artificial neural network works in a similar principle to the human nervous system. The ANN model has a very serious usage in the learning process and estimation of data. The nerve structure called neuron works in connection with many different processing elements. First, these neurons take information from other sources. Next, non-linear operations are applied to this information. Finally, the final output is obtained [37]. In this study, the drying parameters obtained for the drying of different products in a solar assisted dryer were estimated with ANN. Different ANN models (total of 3 layers) were performed for each drying performance parameters. A total of 3 layers were performed to estimate drying rate, convective heat transfer coefficient and collector efficiency values. The input layer, which is the first of these layers for drying rate and convective heat transfer coefficient, consists of 8 neurons. The input layer for collector efficiency consists of 6 neurons. For all performance parameters, the first of the hidden layers consists of 10 neurons and the second consists of 1 neuron. Finally, there is 1 neuron in the output layer. In the information sets of drying rate, convective heat transfer coefficient and collector efficiency parameters, there are 312 input and 39 output, 320 input and 40 output, 240 input and 40 output information respectively. $60 \%$ of this information was used in the training process and $20 \%$ in the validation process and the test process. Feed Forward Back Propagation Algorithm, which has the most common usage as learning algorithm, has been selected. Levenberg Marquardt Algorithm was used for tra-

Table 3. The input and output values used for polynomial SVM models and ANN model to predict DR

\begin{tabular}{|c|c|c|c|c|c|c|c|}
\hline \multicolumn{8}{|c|}{ Input } \\
\hline & Unit & \multicolumn{3}{|c|}{ Min } & \multicolumn{3}{|c|}{ Max } \\
\hline & & Apple & R. Pepper & G. Pepper & Apple & R. Pepper & G. Pepper \\
\hline Drying time & Min. & 15 & 15 & 15 & 585 & 585 & 585 \\
\hline Radiation (I) & $\mathrm{W} / \mathrm{m}^{2}$ & 33.77 & 27.91 & 12.37 & 1033.27 & 944.33 & 872.06 \\
\hline Ambient Temperature $\left(T_{i}\right)$ & ${ }^{\circ} \mathrm{C}$ & 26.54 & 26.33 & 26.18 & 37.62 & 33.43 & 32.74 \\
\hline Ambient Rel. Hum. (Rh & $\%$ & 16.66 & 48.71 & 50.65 & 42.92 & 69.12 & 75.29 \\
\hline Chamber Temperature $\left(T_{c}\right)$ & ${ }^{\circ} \mathrm{C}$ & 30.77 & 29.42 & 30.52 & 49.33 & 44.65 & 44.28 \\
\hline Chamber Rel. Hum. (Rh $)$ & $\%$ & 7.37 & 28.17 & 27.23 & 37.23 & 61.58 & 67.83 \\
\hline Product Temperature $\left(T_{p}\right)$ & ${ }^{\circ} \mathrm{C}$ & 21.53 & 23.37 & 26.82 & 40.21 & 35.41 & 38.46 \\
\hline Product Weight $\left(W_{p}\right)$ & $\mathrm{g}$ & 267.65 & 901.38 & 879.85 & 1141.26 & 1753.54 & 1524.39 \\
\hline \multicolumn{8}{|c|}{ Output } \\
\hline & Unit & \multicolumn{3}{|c|}{ Min } & \multicolumn{3}{|c|}{ Max } \\
\hline & & Apple & R. Pepper & G. Pepper & Apple & R. Pepper & G. Pepper \\
\hline DR & $\begin{array}{c}\left(\mathrm{g}_{\mathrm{w}} / \mathrm{g}_{\mathrm{dm}}\right) / \\
\min \end{array}$ & 0.0002 & 0.0029 & $\begin{array}{c}0.0007 \times 10 \\
2\end{array}$ & 0.0221 & 0.0216 & 0.0219 \\
\hline
\end{tabular}


Table 4. The input and output values used for polynomial SVM models and ANN model to predict $h_{c}$

\begin{tabular}{|c|c|c|c|c|c|c|c|}
\hline \multicolumn{8}{|c|}{ Input } \\
\hline & Unit & \multicolumn{3}{|c|}{ Min } & \multicolumn{3}{|c|}{ Max } \\
\hline & & Apple & R. Pepper & G. Pepper & Apple & R. Pepper & G. Pepper \\
\hline Drying time & Min. & 0 & 0 & 0 & 585 & 585 & 585 \\
\hline Radiation (I) & $\mathrm{W} / \mathrm{m}^{2}$ & 33.77 & 27.91 & 12.37 & 1033.27 & 944.33 & 872.06 \\
\hline Ambient Temperature $\left(T_{i}\right)$ & ${ }^{\circ} \mathrm{C}$ & 25.88 & 26.33 & 25.52 & 37.62 & 33.43 & 32.74 \\
\hline Ambient Rel. Hum. (Rh $\left.{ }_{i}\right)$ & $\%$ & 16.66 & 45.18 & 50.65 & 44.10 & 69.12 & 76.83 \\
\hline Chamber Temperature $\left(T_{c}\right)$ & ${ }^{\circ} \mathrm{C}$ & 29.05 & 29.42 & 30.38 & 49.33 & 44.65 & 44.28 \\
\hline Chamber Rel. Hum. (Rh $)$ & $\%$ & 7.37 & 28.17 & 27.23 & 39.16 & 61.58 & 67.83 \\
\hline Product Temperature $\left(T_{p}\right)$ & ${ }^{\circ} \mathrm{C}$ & 20.62 & 23.33 & 25.77 & 40.21 & 35.41 & 38.46 \\
\hline Product Weight $\left(\mathrm{W}_{\mathrm{p}}\right)$ & $\mathrm{g}$ & 267.65 & 901.38 & 879.85 & 1172.35 & 1777.50 & 1545.03 \\
\hline \multicolumn{8}{|c|}{ Output } \\
\hline & Unit & \multicolumn{3}{|c|}{ Min } & \multicolumn{3}{|c|}{ Max } \\
\hline & & Apple & R. Pepper & G. Pepper & Apple & R. Pepper & G. Pepper \\
\hline$h_{c}$ & $\mathrm{~W} / \mathrm{m}^{2} \mathrm{~K}$ & 1.3923 & 3.9663 & 2.2716 & 1.4229 & 3.9907 & 2.2960 \\
\hline
\end{tabular}

Table 5. The input and output values used for polynomial SVM models and ANN model to predict $\eta_{c}$

\begin{tabular}{|c|c|c|c|c|c|c|c|}
\hline \multicolumn{8}{|c|}{ Input } \\
\hline & Unit & \multicolumn{3}{|c|}{ Min } & \multicolumn{3}{|c|}{ Max } \\
\hline & & Apple & R. Pepper & G. Pepper & Apple & R. Pepper & G. Pepper \\
\hline Drying time & Min. & 0 & 0 & 0 & 585 & 585 & 585 \\
\hline Radiation (I) & $\mathrm{W} / \mathrm{m}^{2}$ & 33.77 & 27.91 & 12.37 & 1033.27 & 944.33 & 872.06 \\
\hline Ambient Temperature $\left(T_{i}\right)$ & ${ }^{\circ} \mathrm{C}$ & 25.88 & 26.33 & 25.52 & 37.62 & 33.43 & 32.74 \\
\hline Ambient Rel. Hum. (Rhi) & $\%$ & 16.66 & 45.18 & 50.65 & 44.10 & 69.12 & 76.83 \\
\hline Chamber Temperature $\left(T_{c}\right)$ & ${ }^{\circ} \mathrm{C}$ & 29.05 & 29.42 & 30.38 & 49.33 & 44.65 & 44.28 \\
\hline Chamber Rel. Hum. (Rhc) & $\%$ & 7.37 & 28.17 & 27.23 & 39.16 & 61.58 & 67.83 \\
\hline \multicolumn{8}{|c|}{ Output } \\
\hline & Unit & \multicolumn{3}{|c|}{ Min } & \multicolumn{3}{|c|}{ Max } \\
\hline & & Apple & R. Pepper & G. Pepper & Apple & R. Pepper & G. Pepper \\
\hline$\eta_{\mathrm{c}}$ & $\%$ & 12.85 & 37.03 & 34.69 & 56.93 & 53.36 & 57.53 \\
\hline
\end{tabular}

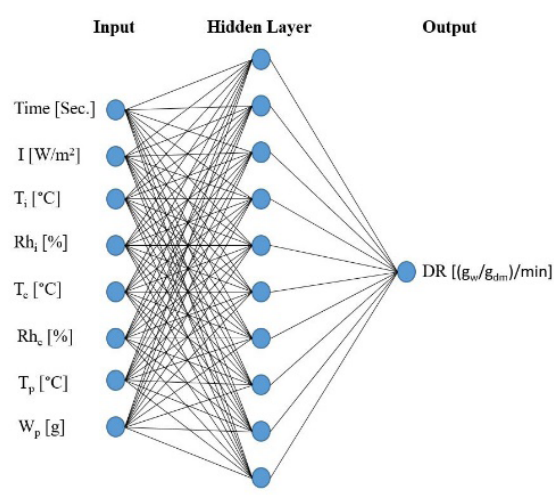

(a)

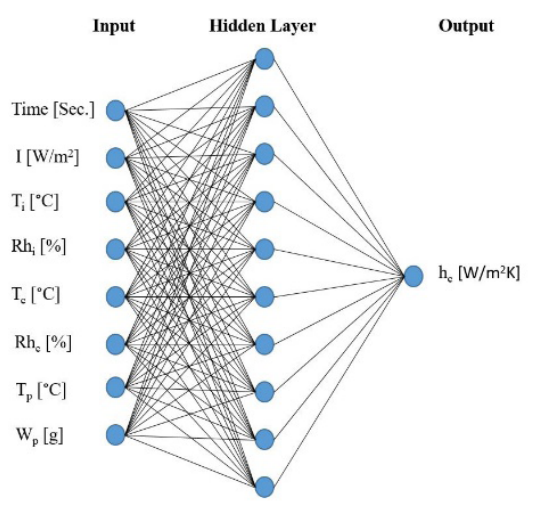

(b)

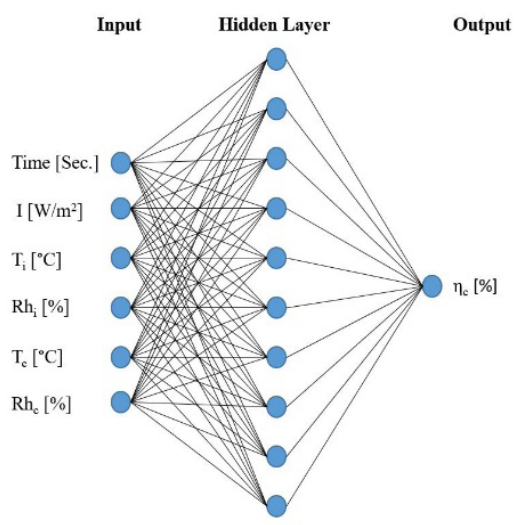

(c)

Figure 2. ANN structures for drying rate-DR (a), convective heat transfer coefficient- $h_{c}(b)$ and solar collector efficiency- $\eta_{c}(c)$ 
ining. The TANSIG function was selected as the Activation Function. The input and output values of DR, $h_{c}$ and $\eta_{c}$ used for polynomial SVM models and ANN model were given in Table 3-5 respectively. Since there are different input parameters that affect each performance parameter, different input values were applied to predict all performance parameters. Figure 2 shows the network structures performed to estimate drying rate, convective heat transfer coefficient and collector efficiency parameters by ANN.

\subsection{3. Accuracy Criteria}

In this study, different food products were dried with a solar energy assisted dryer and $D R, h_{c}$ and $\eta_{c}$ values were obtained from the experiments [24]. In addition, these performance parameters were estimated by polynomial SVM models and ANN model. In order to determine the performance of the predictions, the accuracy criteria, Root Mean Square Error (RMSE) and Mean Absolute Error (MAE) values were taken into consideration. These accuracy criteria are determined by using equation 18 and 19 [38].

$$
\begin{aligned}
& \text { RMSE }=\sqrt{\frac{1}{n} \sum_{i=1}^{n} e_{i}{ }^{2}} \\
& M A E=\frac{1}{n} \sum_{i=1}^{n}\left|e_{i}\right|
\end{aligned}
$$

Here, e is the difference between the actual value and the estimated value, $n$ is the number of data.

\section{RESULTS AND DISCUSSION}

In this study, firstly the drying characteristics $\left(D R, h_{c}\right.$ and $\eta_{c}$ ) of different products (apple, red pepper and green pepper) dried with a solar energy assisted drying system were analyzed by using the experiments [24] carried out in the climate conditions of Osmaniye province. Then DR, $h_{c}$ and $\eta_{c}$ values were estimated using polynomial SVM models and ANN model. Variation of $\eta_{c}$ during drying process for different products is given in Figure 3. The efficiency value of the solar collector varies between $13-58 \%$ for apple drying process, between $37-53 \%$ for red pepper drying process and between $34-57 \%$ for green pepper drying process [24].

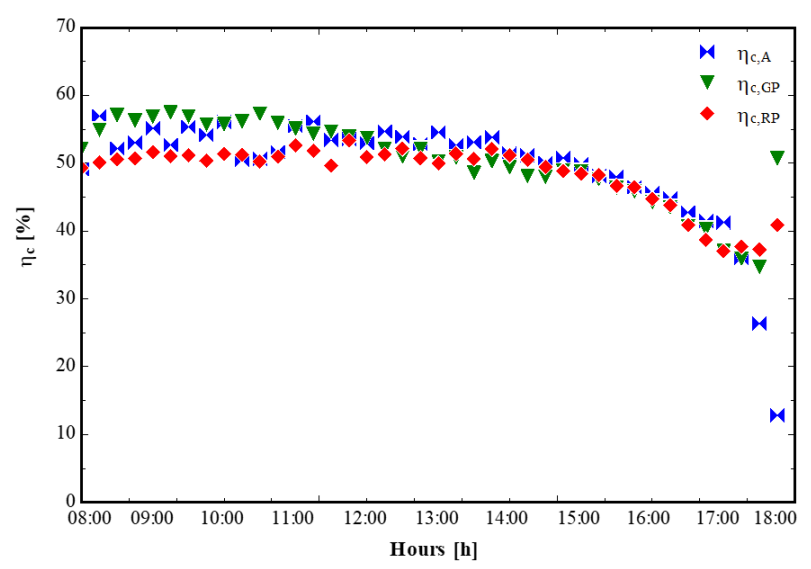

Figure 3. Variation of $\eta_{c}$ during drying process for different product [24]
Figure 4 and 5 exhibit variation of the DR and $h_{c}$ values for drying process of different products, respectively. It has been observed that the rate of drying has decreased over time and DR values varied between $0.0194 \times 10^{-2}$ and 2.2091 $\left(\mathrm{g}_{\mathrm{w}} / \mathrm{g}_{\mathrm{dm}}\right) / \mathrm{min}$ for apple, between $0.2872 \times 10^{-2}$ and $2.1594\left(\mathrm{~g}_{\mathrm{w}} /\right.$ $\left.\mathrm{g}_{\mathrm{dm}}\right) / \mathrm{min}$ for red pepper, $0.0007 \times 10^{-2}$ and $2.1850\left(\mathrm{~g}_{\mathrm{w}} / \mathrm{g}_{\mathrm{dm}}\right) /$ min for green pepper. The average DR values were found as $0.8034 \times 10^{-2}\left(\mathrm{~g}_{\mathrm{w}} / \mathrm{g}_{\mathrm{dm}}\right) / \mathrm{min}$ for apple slices, $0.9960 \times 10^{-2}\left(\mathrm{~g}_{\mathrm{w}} /\right.$ $\left.\mathrm{g}_{\mathrm{dm}}\right) / \mathrm{min}$ for red pepper slices, $1.0299 \times 10^{-2}\left(\mathrm{~g}_{\mathrm{w}} / \mathrm{g}_{\mathrm{dm}}\right) / \mathrm{min}$ for green pepper slices. During the drying process, $h_{c}$ values were varied between 1.3923 and $1.4230 \mathrm{~W} / \mathrm{m}^{2} \mathrm{~K}$ for apple slices, between 3.9663 and $3.9907 \mathrm{~W} / \mathrm{m}^{2} \mathrm{~K}$ for red pepper slices, between 2.2715 and $2.2960 \mathrm{~W} / \mathrm{m}^{2} \mathrm{~K}$ for green pepper slices. The average $h_{c}$ values were found as $1.4134 \mathrm{~W} / \mathrm{m}^{2} \mathrm{~K}$ for apple, $3.9801 \mathrm{~W} / \mathrm{m}^{2} \mathrm{~K}$ for red pepper slices, $2.2877 \mathrm{~W} / \mathrm{m}^{2} \mathrm{~K}$ for green pepper slices. In addition, $\mathrm{C}$ and $\mathrm{n}$ constant values were found as 1.0053 and 0.2509 for apple slices, 1.0003 and 0.3692 for red pepper slices and 1.0008 and 0.3062 for green pepper slices, respectively [24].

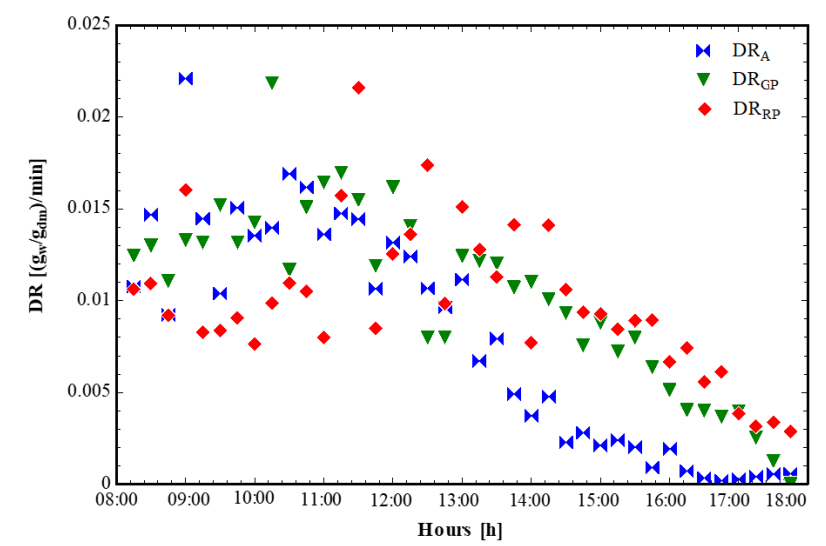

Figure 4. Variation of the DR values during drying process for different product [24]

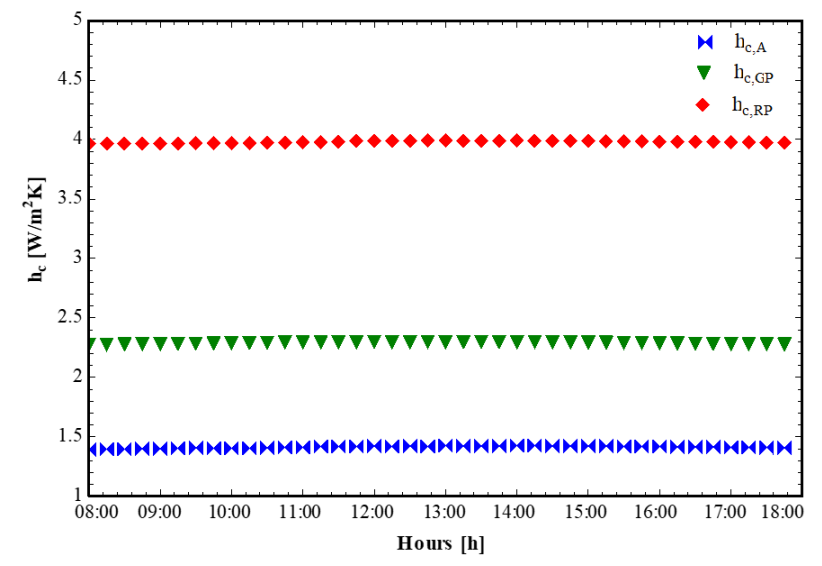

Figure 5. Variation of $h_{c}$ values during drying process for different product [24]

In this study, DR, $h_{c}$ and $\eta_{c}$ values obtained by drying apple, red pepper and green pepper in a solar assisted dryer were estimated by polynomial SVM and ANN models. RMSE and MAE values given in Table 6 are used to determine the performance of the estimations. DR values are best predicted by the ANN model for all products. The $h_{c}$ values of apple slices were best estimated by SVM $\mathrm{L}_{\mathrm{L}}$ model, but the $\mathrm{h}_{\mathrm{c}}$ values of red pepper and green pepper slices were best estimated by ANN model. Estimation of experimentally obtained $\eta_{c}$ 
values during drying of all products was performed by the best $\mathrm{SVM}_{\mathrm{C}}$ method. Table 7 shows the accuracy criteria obtained for performance parameters in the literature. It was observed that the accuracy criteria obtained in this study give acceptable results when compared with the literature.

Table 6. Accuracy results of the models

\begin{tabular}{|c|c|c|c|c|c|c|}
\hline $\begin{array}{c}\text { Parame- } \\
\text { ter }\end{array}$ & Product & Model & RMSE & MAE & $\mathrm{R}^{2}$ & $\begin{array}{l}\text { Epo- } \\
\text { ch }\end{array}$ \\
\hline \multirow[t]{12}{*}{ DR } & Apple & ANN & 0.001066408 & 0.000584221 & 0.9698 & 20 \\
\hline & & $\mathrm{SVM}_{\mathrm{L}}$ & 0.002833013 & 0.002346657 & 0.7837 & - \\
\hline & & $\mathrm{SVM}_{\mathrm{O}}$ & 0.002590737 & 0.001992391 & 0.8431 & - \\
\hline & & $\mathrm{SVM}_{\mathrm{C}}$ & 0.003173243 & 0.002532474 & 0.7376 & - \\
\hline & Red Pepper & ANN & 0.002125115 & 0.001632173 & 0.7176 & 6 \\
\hline & & SVM $_{L}$ & 0.002542184 & 0.002032765 & 0.6159 & - \\
\hline & & $\mathrm{SVM}_{\mathrm{Q}}$ & 0.004775523 & 0.003932029 & 0.1713 & - \\
\hline & & $\mathrm{SVM}_{\mathrm{C}}$ & 0.007077473 & 0.005503955 & 0.3938 & - \\
\hline & $\begin{array}{l}\text { Green } \\
\text { Pepper }\end{array}$ & ANN & 0.001950538 & 0.001467057 & 0.8560 & 12 \\
\hline & & $\mathrm{SVM}_{\mathrm{L}}$ & 0.003412684 & 0.002752114 & 0.7796 & - \\
\hline & & $\mathrm{SVM}_{\mathrm{Q}}$ & 0.008181755 & 0.006227085 & 0.0437 & - \\
\hline & & $\mathrm{SVM}_{\mathrm{C}}$ & 0.009192591 & 0.006368667 & 0.1501 & - \\
\hline \multirow[t]{12}{*}{$h_{c}$} & Apple & ANN & 0.000700034 & 0.000583431 & 0.9961 & 11 \\
\hline & & $\mathrm{SVM}_{\mathrm{L}}$ & 0.000647039 & 0.000551914 & 0.9965 & - \\
\hline & & $\mathrm{SVM}_{\mathrm{Q}}$ & 0.000852939 & 0.000712349 & 0.9942 & - \\
\hline & & $\mathrm{SVM}_{\mathrm{c}}$ & 0.001756525 & 0.001559501 & 0.9722 & - \\
\hline & Red Pepper & ANN & 0.000315103 & 0.000247558 & 0.9991 & 13 \\
\hline & & $S_{V} M_{L}$ & 0.000939006 & 0.000887537 & 0.9968 & - \\
\hline & & $\mathrm{SVM}_{\mathrm{Q}}$ & 0.001043954 & 0.000933099 & 0.9866 & - \\
\hline & & $\mathrm{SVM}_{\mathrm{c}}$ & 0.002441669 & 0.001954482 & 0.9300 & - \\
\hline & Green Pepper & ANN & 0.000289112 & 0.000208491 & 0.9987 & 20 \\
\hline & & $S_{V M}$ & 0.000632797 & 0.00088158 & 0.9962 & - \\
\hline & & $\mathrm{SVM}_{\mathrm{Q}}$ & 0.00102846 & 0.000532599 & 0.9947 & - \\
\hline & & $\mathrm{SVM}_{\mathrm{c}}$ & 0.002634382 & 0.001932113 & 0.9296 & - \\
\hline \multirow[t]{12}{*}{$\eta_{\mathrm{c}}$} & Apple & ANN & 1.317713639 & 0.986534597 & 0.9766 & 9 \\
\hline & & $S V M_{L}$ & 3.969052479 & 1.749772308 & 0.8240 & - \\
\hline & & $\mathrm{SVM}_{\mathrm{Q}}$ & 1.638731971 & 1.065426984 & 0.9701 & - \\
\hline & & $\mathrm{SVM}_{\mathrm{C}}$ & 0.800964654 & 0.661964769 & 0.9912 & - \\
\hline & Red Pepper & ANN & 0.611879421 & 0.448985972 & 0.9824 & 6 \\
\hline & & $S V M_{L}$ & 1.693990697 & 1.218770976 & 0.8646 & - \\
\hline & & $\mathrm{SVM}_{\mathrm{Q}}$ & 0.858459749 & 0.594509268 & 0.9653 & - \\
\hline & & $\mathrm{SVM}_{\mathrm{c}}$ & 0.424738967 & 0.314045676 & 0.9914 & - \\
\hline & Green Pepper & ANN & 3.005891005 & 1.245582428 & 0.7960 & 6 \\
\hline & & $S_{V} M_{L}$ & 2.735130978 & 1.17323392 & 0.8175 & - \\
\hline & & $\mathrm{SVM}_{\mathrm{Q}}$ & 2.631461549 & 1.001995357 & 0.8365 & - \\
\hline & & $\mathrm{SVM}_{\mathrm{c}}$ & 0.486331346 & 0.457946875 & 0.9938 & - \\
\hline
\end{tabular}

Comparison of experimental data and ANN model, which is the best converge to DR, for three different food products, is given in Figure 6, $\mathrm{R}^{2}$ values were 0.9698 (apple), 0.7176 (red pepper) and 0.8560 (green pepper) for the DR values estimated by ANN. Figure 7 shows the comparison of the models with the best convergence of the $h_{c}$ parameter obtained in the drying of different food products with experimental data. While $S_{V M}$ model had the highest $R^{2}$ value $(0.9965)$ for the $h_{c}$ of apple product, the highest $R^{2}$ values of red pepper and green pepper products were obtained from ANN models (0.9991 and 0.9987). Figure 8 presents the comparison of the models $\left(\mathrm{SVM}_{\mathrm{C}}\right)$ that best converge the $\eta_{\mathrm{c}}$ parameters obtained during the drying of three different products with experimental data. $\mathrm{R}^{2}$ values obtained from $\mathrm{SVM}_{\mathrm{C}}$ model for apple, red pepper and green pepper were found as 0.9912, 0.9914 and 0.9938 , respectively. In the study, it was observed that the machine learning models used to estimate the parameters affecting the food drying converged each parameter differently. Therefore, it has been concluded that the most suitable model for utilization among the models formed to estimate each performance parameter is important.

\begin{tabular}{|c|c|c|c|c|c|}
\hline Product & $\begin{array}{l}\text { Drying } \\
\text { method }\end{array}$ & $\begin{array}{l}\text { Output } \\
\text { parame- } \\
\text { ters }\end{array}$ & Input variables & Result & Ref. \\
\hline Grape & $\begin{array}{l}\text { Green- } \\
\text { house }\end{array}$ & $h_{c}$ & $\begin{array}{l}\text { Drying Time, Am- } \\
\text { bient Temperature, } \\
\text { Product Tempe- } \\
\text { rature, Relative } \\
\text { Humidity, Reynolds } \\
\text { Number. Prandtl } \\
\text { Number, Radiation }\end{array}$ & $\begin{aligned} \mathrm{MAE}_{\text {MLP }} & =0.0815 \\
\mathrm{RMSE}_{\text {MLP }} & =0.1088\end{aligned}$ & {$[18]$} \\
\hline Potato & $\begin{array}{l}\text { Indirect } \\
\text { Solar } \\
\text { Dryer }\end{array}$ & DR & $\begin{array}{l}\text { Air temperature, } \\
\text { Drying Time, Air } \\
\text { velocity, Product } \\
\text { type, Drying time }\end{array}$ & $\begin{array}{c}\mathrm{R}_{\mathrm{ANN}}^{2}=0.9752-\mathrm{R}^{2}{ }_{\mathrm{AN}-} \\
=0.9900\end{array}$ & [19] \\
\hline Kiwifruit & $\begin{array}{l}\text { Hybrid } \\
\text { Hot Air- } \\
\text { Infrared } \\
\text { Dryer }\end{array}$ & DR & $\begin{array}{l}\text { Time, IR Lamps, Air } \\
\text { Temperature } \\
\text { and Air Velocity }\end{array}$ & $\begin{aligned} \mathrm{R}_{\mathrm{ANN}}{ }^{2} & =0.9998 \\
\mathrm{MSE}_{\mathrm{ANN}} & =3.5 \mathrm{E}-5\end{aligned}$ & {$[20]$} \\
\hline - & Solar still & $\begin{array}{l}\text { Thermal } \\
\text { Efficien- } \\
\text { cy }\left(\eta_{c}\right)\end{array}$ & $\begin{array}{c}\text { Julian day, Ambient } \\
\text { Temperature, Wind } \\
\text { Speed, Relative Hu- } \\
\text { midity, Solar Radia- } \\
\text { tion, Total Dissolved } \\
\text { Solids of Feed, } \\
\text { Total Dissolved } \\
\text { Solids of Brine }\end{array}$ & $\mathrm{RMSE}_{\mathrm{ANN}}=1.147$ & {$[21]$} \\
\hline
\end{tabular}

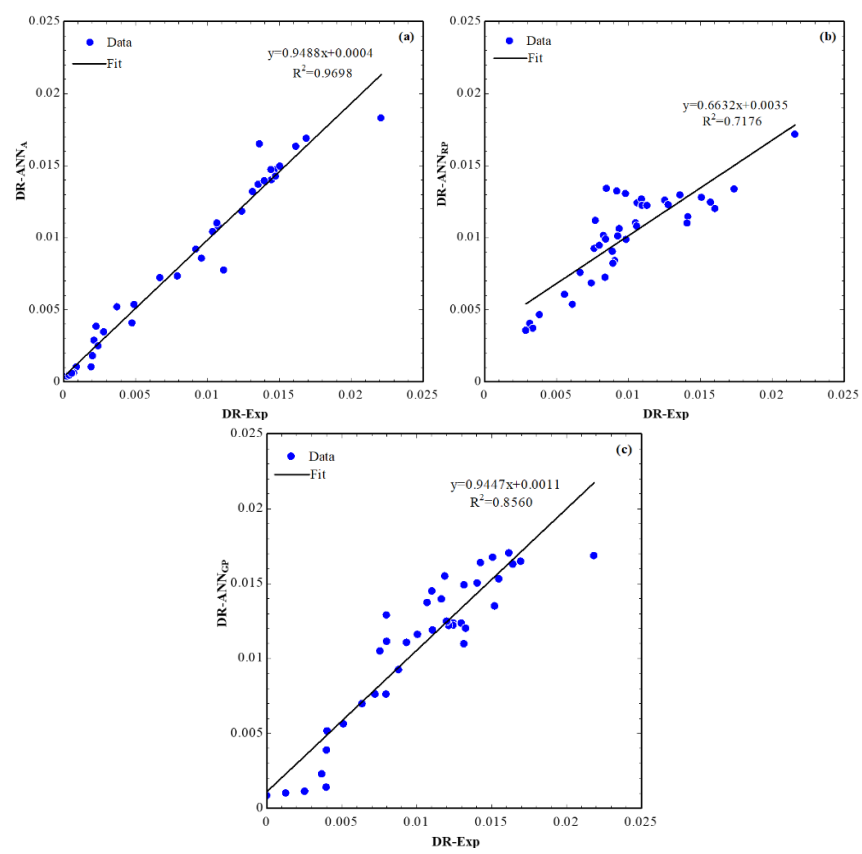

Figure 6. The comparison of experimental data and models which best converges to the DR parameters for apple (a), red pepper (b) and green pepper (c) 


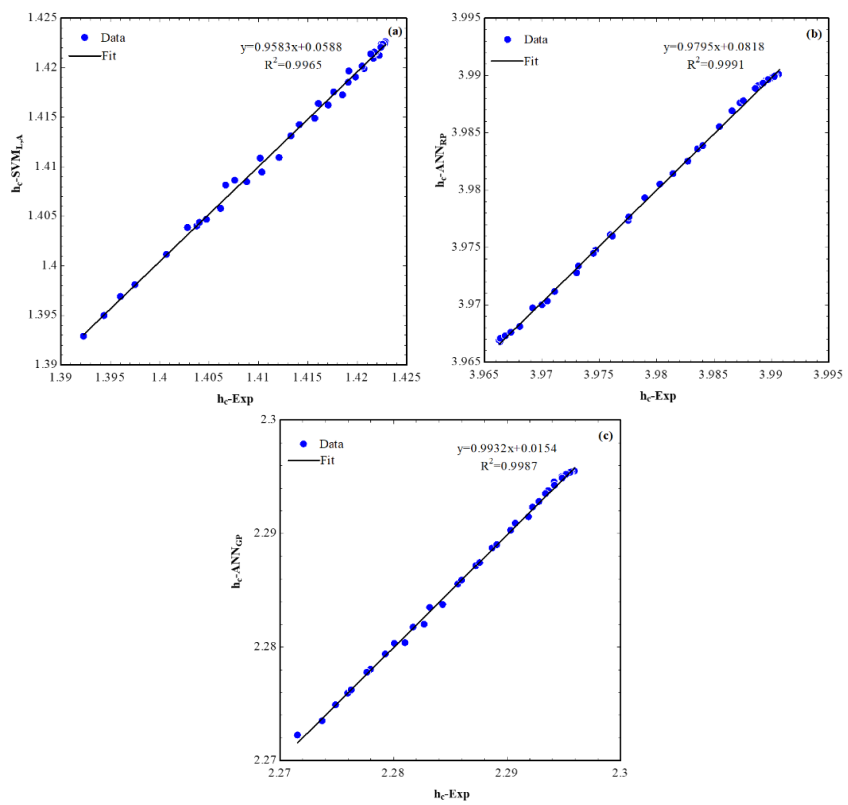

Figure 7. The comparison of experimental data and models which best converges to the $h_{c}$ parameters for apple (a), red pepper (b) and green pepper (c)

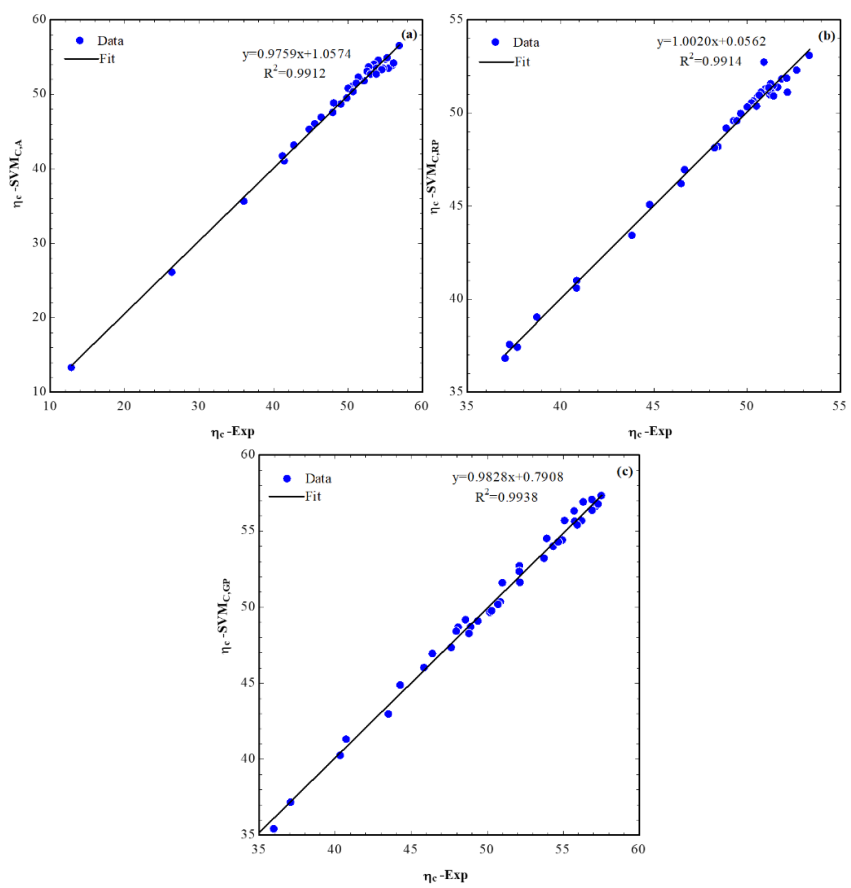

Figure 8. The comparison of experimental data and models which best converges to the $\eta_{c}$ parameters for apple (a), red pepper (b) and green pepper (c)

\section{CONCLUSION}

In this study, the performance parameters obtained from an experimental study in the literature [24] were estimated by using computational intelligence models. Apple, red pepper and green pepper slices were dried in the solar energy assisted system. Different parameters such as temperature, humidity, radiation and weight were measured during the experiments. DR, $h_{c}$ and $\eta_{c}$ values were calculated using experimental data [24]. It was shown from the experimental results that DR and $h$ values vary according to the structure, porosity, shape, thermophysical properties and experimental conditions of the product. It was determined that $\eta_{\mathrm{c}}$ parameter affected by climatic conditions. The DR, $h_{c}$ and $\eta_{\mathrm{c}}$ values were estimated by using polynomial SVM models and ANN model. The best results were obtained from the ANN model and $S V M_{C}$ model for estimating DR and $\eta_{c}$ values for three different products, respectively. The best estimate of the $h_{c}$ values of both products except apple product was performed with ANN model. However, the best convergence was obtained by $\mathrm{SVM}_{\mathrm{L}}$ model for estimating the $\mathrm{h}_{\mathrm{c}}$ value of apple product. It was observed from the study that the models formed for each parameter converged differently and parameters which are particularly important in drying systems designs should be modeled accurately. It was also observed that in general, the results obtained converged well compared to the results obtained in the literature and these results were acceptable. The results obtained from this study are useful for modeling drying performance parameters with different computational intelligence methods.

\section{CONFLICTS OF INTEREST}

This study was supported by the Scientific Research Projects Unit of Osmaniye Korkut Ata University (OKÜBAP) within the scope of the project named as OKÜBAP-2014-PT3-032. Thanks to OKÜBAP for their support. We are also very grateful to the reviewers for their valuable comments, which have been utilized to improve the quality of the paper.

\section{REFERENCES}

[1] Kant, K., Shukla, A., Sharma, A., Kumar, A., Jain, A. (2016). Thermal energy storage based solar drying systems: A review, Innovative Food Science and Emerging Technologies, 34: 86-99. doi: 10.1016/j. ifset.2016.01.007

[2] Akman, H. (2017). Thermodynamic Analysis of a Solar Energy Assisted Drying System (MSc Thesis), Osmaniye Korkut Ata University, Osmaniye.

[3] Akman, H., Çerci, K., and Hürdoğan, E. (2017). Design and Manufacture of a Solar Energy Assisted Drying System and Evaluation of First Experiment Results, International Advanced Researches \& Engineering Congress, 1-14. Osmaniye.

[4] Mustayen, A. G. M. B., Mekhilef, S., Saidur, R. (2014). Performance study of different solar dryers: A review. Renewable and Sustainable Energy Reviews, 34, 463-470. doi: 10.1016/j.rser.2014.03.020.

[5] Stritih, U., Osterman, E., Evliya, H., Butala, V., Paksoy, H. (2013). Exploiting solar energy potential through thermal energy storage in Slovenia and Turkey. Renewable and Sustainable Energy Reviews, $25,442-461$.

[6] Wang, H., Zhang, M., Mujumdar, A. S. (2014). Comparison of three new drying methods for drying characteristics and quality of shiitake mushroom (Lentinus edodes). Drying Technology, 32(15): 1791-1802.

[7] Çerçi, K. N., Süfer, Ö., Söyler, M., Hürdoğan, E., Özalp, C. (2018). Thin layer drying of zucchini in solar dryer located in Osmaniye region. Tehnički glasnik, 12(2): 79-85.

[8] Togrul, I. T. (2005). Convective heat transfer coefficient of apricots under open sun drying conditions. Chemical Engineering Communications, 192(8), 1036-1045.

[9] Cerci, K. N., \& Akpinar, E. K. (2016). Experimental determination of convective heat transfer coefficient during open sun and green- 
house drying of apple slices. Journal of Thermal Engineering, 2: 741747.

[10] Jain, D., Mridula, D., Patil, R. T., Barnwal, P., Kumar, R. (2010). Kinetics of convective heat and mass transfer coefficient of green chilli during open-sun and greenhouse drying. Desalination and water treatment, 24(1-3): 38-46. doi: 10.5004/dwt.2010.1152

[11] Zhu, A. (2018). The convective hot air drying of Lactuca sativa slices. International Journal of Green Energy, 15(3): 201-207. doi: 10.1080/15435075.2018.1434523

[12] Oko, C. O. C., Nnamchi, S. N. (2013). Coupled heat and mass transfer in a solar grain dryer. Drying Technology, 31(1): 82-90. doi: 10.1080/07373937.2012.719561

[13] Amer, B. M., Gottschalk, K., \& Hossain, M. A. (2018). Integrated hybrid solar drying system and its drying kinetics of chamomile. Renewable Energy, 121: 539-547. doi: 10.1016/j.renene.2018.01.055

[14] Kooli, S., Fadhel, A., Farhat, A., \& Belghith, A. (2007). Drying of red pepper in open sun and greenhouse conditions.: mathematical modeling and experimental validation. Journal of Food Engineering: 79(3): 1094-1103. doi: 10.1016/j.jfoodeng.2006.03.025

[15] Anwar, S. I., Tiwari, G. N. (2001). Heat and mass transfer coefficients in a four-tray solar crop drying system. International Journal of Ambient Energy, 22: 48-56. doi: 10.1080/01430750.2001.9675386

[16] Sagia, A. S,. Fragkou, D.V. (2014). Influence of drying conditions and mathematical models on the drying curves and the moisture diffusivity of mushrooms. Journal of Thermal Engineering, 1: 236-244.

[17] Doymaz, I., Kipcak, A.S. (2018). Investigation of infrared drying of pomegranate by-products. Journal of Thermal Engineering, 4: 18211827.

[18] Çerçi, K. N., Daş, M. (2019). Modeling of heat transfer coefficient in solar greenhouse type drying systems. Sustainability, 11(18): 5127. doi: 10.3390/su11185127

[19] Kaveh, M., Sharabiani, V.R., Chayjan, R.A., Taghinezhad, E., Abbaspour-Gilandeh, Y., Golpour, I. (2018). ANFIS and ANNs model for prediction of moisture diffusivity and specific energy consumption potato, garlic and cantaloupe drying under convective hot air dryer. Information Processing in Agriculture, 5: 372-387.

[20] Nadian, M.H., Abbaspour-Fard, M.H., Martynenko, A., Golzarian, M.R. (2017). An intelligent integrated control of hybrid hot air-infrared dryer based on fuzzy logic and computer vision system. Computers and Electronics in Agriculture, 137: 138-149.

[21] Mashaly, A.F., Alazba A.A. (2016). Comparison of ANN, MVR, and SWR models for computing thermal efficiency of a solar still. International Journal of Green Energy, 10: 1016-1025.

[22] Celebi, K., Uludamar, E., Tosun, E., Yildizhan, S., Aydin, K., Ozcanli, M. (2017). Experimental and artificial neural network approach of noise and vibration characteristic of an unmodified diesel engine fuelled with conventional diesel, and biodiesel blends with natural gas addition. Fuel, 197:159-173. doi: 10.1016/j.fuel.2017.01.113

[23] Bilgili, M., Şahin, B., Yaşar, A. (2007). Application of artificial neural networks for the wind speed prediction of target station using reference station data. Renewable Energy, 32: 2350-2360. doi: 10.1016/j. renene.2006.12.001

[24] Çerçi, K.N., Saydam, D.B., Hürdoğan, E. (2018). Evaluating the Performance of a Solar Energy Assisted Drying System for Different Food Products in Osmaniye Climatic Conditions, 4th International Conference on Advances in Mechanical Engineering (ICAME-2018), İstanbul, Turkey.

[25] Holman J.P. (2001). Experimental methods for engineers, 8th ed. USA: McGraw Hill.
[26] Oztop. H.F., Bayrak. F., Hepbaslı. A. (2013). Energetic and exergetic aspects of solar air heating (solar collector) systems. Renewable and Sustainable Energy Reviews, 21, 59-83,. doi: 10.1016/j. rser.2012.12.019.

[27] Akpinar, E. K., Toraman, S. (2016). Determination of drying kinetics and convective heat transfer coefficients of ginger slices, Heat Mass Transfer, 52, 2271-2281. doi: 10.1007/s00231-015-1729-6

[28] Anwar, S.I. Tiwari, G.N. (2001). Convective heat transfer coefficient of crop in forced convection drying-an experimental study. Energy Conversion Management, 42: 1687-1698. doi: 10.1016/S01968904(00)00160-6

[29] Li, L.L., Zhao, X., Tseng, M.L., Tan, R.R. (2019). Short-term wind power forecasting based on support vector machine with improved dragonfly algorithm. Journal of Cleaner Production, 118447. doi: 10.1016/j.jclepro.2019.118447

[30] Leong, W.C., Kelani, R.O., Ahmad, Z. (2019). Prediction of air pollution index (API) using support vector machine (SVM), Journal of Environmental Chemical Engineering, 103208. doi: 10.1016/j. jece.2019.103208

[31] Ma, Z., Ye, C., Li, H., Ma, W. (2018). Applying support vector machines to predict building energy consumption in China. Energy Procedia, 152: 780-786. doi: 10.1016/j.egypro.2018.09.245

[32] Fan, J., Wang, X., Wu, L., Zhou, H., Zhang, F., Yu, X., Lu, X., Xiang, Y. (2018). Comparison of support vector machine and extreme gradient boosting for predicting daily global solar radiation using temperature and precipitation in humid subtropical climates: A case study in China. Energy Conversion and Management, 164: 102-111. doi: 10.1016/j.enconman.2018.02.087

[33] Das, M., Akpinar, E. K. (2018). Investigation of Pear Drying Performance by Different Methods and Regression of Convective Heat Transfer Coefficient with Support Vector Machine. Applied Sciences, 8: 215, 1-16. doi:10.3390/app8020215

[34] Vapnik, V. N. (1999). The Nature of Statistical Learning Theory (2nd edition). New York: Springer-Verlag.

[35] Subaira, A.S., and Anitha, P. (2014). Efficient classification mechanism for network intrusion detection system based on data mining techniques: a survey, in: Intelligent Systems and Control (ISCO), 2014 IEEE 8th International Conference On. IEEE, 274-280.

[36] Dos Santos, E. M., Gomes, H. M. (2002). A Comparative Study of Polynomial Kernel SVM Applied to Appearance-Based Object Recognition Pattern Recognition with Support Vector Machines, 408-418, Berlin: Springer.

[37] Ghritlahre, H. K., Prasad, R. K. (2018). Exergetic performance prediction of solar air heater using MLP, GRNN and RBF models of artificial neural network technique. Journal of Environmental Management, 223: 566-575. doi: 10.1016/j.jenvman.2018.06.033

[38] Chai, T., Draxler, R. R. (2014). Root Mean Square Error (RMSE) or Mean Absolute Error (MAE)?-Arguments against avoiding RMSE in literature. Geoscientific Model Development Discussions, 7: $1247-$ 1250. doi: 10.5194/gmd-7-1247-2014 